TEME, г. XLIV, бр. 2, април - јун 2020, стр. 637-654

Прегледни рад

Примљено: 28. 7. 2018.

https://doi.org/10.22190/TEME180728044R

Ревидирана верзија: 19. 10. 2018.

Одобрено за штампу: 15. 4. 2020.

\title{
EVASION IN SERBIAN PARLIAMENTARY QUESTIONS
}

\author{
Aleksandra Radovanović \\ University of Kragujevac, Faculty of Hotel Management and Tourism \\ in Vrnjačka Banja, Vrnjačka Banja, Serbia \\ aleksandra.radovanovic@kg.ac.rs
}

\begin{abstract}
The current study seeks to investigate evasion in Parliamentary Questions in the National Assembly of Serbia. The objectives of the research are to determine whether and how frequently the members of the Government provided evasive responses and how they did it. The analysis comprising a qualitative and a quantitative method was conducted on the data that comprised the transcripts of three Parliamentary Questions. The responses were classified into answers, intermediate responses and evasive responses. Each identified evasive response was analysed in terms of its level of evasion, the practices involved and the agenda shifts that occurred. The results reveal that evasion did occur in the investigated data. As described and exemplified in the study, the medium level of evasion was the most prominent, and the Government members employed overt and covert practices, as well as three types of agenda shifts in evading answers. These results match those observed in previous studies on evasion in Question Time in other parliaments.
\end{abstract}

Key words: evasion, Parliamentary Questions, answer, agenda shifts.

\section{ЕВАЗИВНОСТ У ПОСЛАНИЧКИМ ПИТАЮИМА СКУПШТИНЕ СРБИЈЕ}

\section{Апстракт}

Намера аутора овог рада је да истражи евазивност током посланичких питања у Народној скупштини Србије са циљем да испита да ли су и колико често чланови Владе избегавали одговоре на питања и како су то чинили. Квалитативна и квантитативна анализа спроведена је на материјалу сачињеном од транскрипата посланичких питања са три седнице Скупштине. Одговори су класификовани као „прави одговори", посредни одговори и евазивни одговори, а сваки идентификовани евазивни одговор је потом даље анализиран у погледу нивоа евазивности, примењених техника и промена тема до којих је дошло. Резултати показују да евазивност јесте била присутна у испитиваном језичком материјалу. Као што је у раду описано и поткрепљено примерима, одговори средњег степена евазивности били су најучесталији, а чланови Владе су при избегавању одговора примењивали отворене и прикривене технике, као и три типа промена тема. Ови резултати су у сагласности са резултатима претходних студија о евазивности током посланичких питања у другим парламентима.

Кључне речи: евазивност, посланичка питања, одговор, промене теме. 


\section{INTRODUCTION}

Politicians are frequently perceived as "the sort of people who will not give a straight answer to a straight question" (Bull, 2003, p. 130). Hence, the phenomenon of giving "responses that do not answer the questions" (Rasiah, 2007, p. 9) in political discourse has been the matter of substantial scholarly research under different designations such as equivocation, nonreply, evasion. Numerous studies have provided ample empirical evidence on the occurrence of evasion in political discourse. Yet, as pointed out below, not much research has been done on evasion in parliamentary discourse and question time as one of its representative subgenres. In view of this, this topic is the focus of the current research.

This study seeks to investigate this linguistic feature in Parliamentary Questions, the question time in the National Assembly of Serbia, with the aim to address the following: whether and how frequently the members of the Government provided evasive responses and how they did it. The analysis was conducted on the data that included the transcripts of three Parliamentary Questions. It largely adopted the procedural methods of the previously tested models in similar analyses.

\section{THEORETICAL BACKGROUND}

Investigating political language dates back to the Ancient Greeks and has been a matter of continuing concern within various theoretical frameworks. The research on the phenomenon of evasion in political discourse within the field of social psychology has largely paved the way for subsequent linguistic studies. The researchers have illuminated the phenomenon and stated different causes for the occurrence of equivocation, i.e. evasion. Bavelas et al. (Bavelas, Black, Bryson \& Mullett, 1988, p. 138) view equivocation as "non-straightforward communication", i.e. a situationally imposed departure from essential elements (sender, content, receiver, context) of clear communication, which occurs due to "communicative avoidance-avoidance conflicts". Bull (2003, 2008), on the other hand, embraces the pragmatic notion of face and identifies face management as responsible for equivocation. Far more significant for this study is Bull's contribution on the ways of equivocating.

Based on eight televised political interviews, Bull and Mayer (1993) developed a typology of non-replies that included 12 superordinate categories subdivided into subordinate categories, altogether 35 different ways in which politicians fail to reply to questions. This typology, subsequently slightly altered (Bull, 2003), in some respects overlaps with Partington's (2003) overview of the mechanisms of evasion, which outlines 16 ways of evasion organised in 9 categories. Another noteworthy contribution comes from Clayman $(1993,2001)$ who provided a valuable in-depth overview of the dynamics of evading questions. Starting from the fundamental distinctions 
between answering and evading by reserving the latter term for "actions that are treated as inadequately responsive by the interview participants" (Clayman, 2001, p. 406-407), Clayman identified two dimensions (a negative and a positive one) and two sets of practices (overt and covert) in 'resisting' questions. These works highlighted the evasiveness in political talk in English-speaking countries (British (Bull \& Mayer, 1993; Bull, 2003), American (Clayman, 2001; Partington 2003)) and heavily influenced the subsequent research that compared evasion practices of politicians of different nationalities (e.g. British, American and Montenegrin (Vuković, 2013a); American and Malaysian (Hanafe \& Thani, 2016)). However, the research has been largely confined to the context of political media interviews, whereas evasion in parliamentary discourse remains largely unexplored.

Parliamentary discourse, as a genre of the wider field of political discourse (Ille 2015) that represents its most formal and institutionalised variety (Bayley, 2004, p. 1), was not a matter of much linguistic concern until the 1980's (Bayley, 2004; Ille, 2006). As Ille (2015, p. 1113) points out, parliamentary discursive practices not only reflect political, social, and cultural configurations, but they also contribute to shaping these configurations discursively, cross-rhetorically, and cross-culturally. Hence, the analyses of usages and functions of parliamentary language can, in a way, enlighten political behaviour, on the one hand, and enable crosscultural comparisons of (pragma)linguistic features, on the other.

As regards the major scholarly contributions to this field, one has to name the work of Ille (2004a, b, 2006, 2010, 2015), van Dijk (2000, 2004, 2005) and Bayley (2004) who have inspired further studies. The research has been mostly set within the fields of pragmalinguistics, cognitive linguistics, discourse analysis and critical discourse analysis frequently adopting interdisciplinary perspectives. Studies have addressed diverse pragmalinguistic features and notions (insulting (Ille, 2004a), interruption patterns (Ille, 2004b), political implicatures (van Dijk, 2005) politeness (Murphy, 2014), as well as the pragmalinguistic use of grammatical categories (epistemic modals (Vukovic, 2014)) frequently in a crosslinguistic perspective. Although the greatest attention has reasonably been given to the UK parliament (Ille, 2004b; Murphy, 2014; Vukovic, 2014), the parliamentary language in other settings has also found in the focus of the research (Swedish (Ille 2004a, 2010). As for Serbia and the region, the mention should be given to the extensive research carried out by Vuković who has shed new light not only on the phenomenon of modality (weak epistemic modality (Vuković, 2013b), deontic modality (Vuković Stamatović, 2016)) in parliamentary discourse, but also on evasion in political discourse of a neighboring country (Vuković, 2013a). The speech acts of apologies in Serbian Parliament have also appeared in the focus of one study (Векарић Јелић, 2014). 
Parliamentary discourse complies with specific rules and conventions of a particular setting (Ille, 2006). Since it is meant to serve various institutionally specific purposes, several subgenres can be identified. According to Ille (2015), these are the "procedure based communicative interactive tools that are subordinated to specific parliamentary goals," the most representative of which are: ministerial statements, interpellations, parliamentary speeches, parliamentary debates, parliamentary (oral and written) questions, and question time. Question Time, the questioning procedure in the UK parliament, is one of the prototypical forms of parliamentary questioning. Although in comparison to the other subgenres, question time has caught the significant scholars' attention, the research on evasion in this subgenre lacks.

A reference to the politics of evasion in the UK House of Commons was made by Crystal (1997) in his seminal Encyclopedia. Beard (2000) also provided some informative insights on evasion in Parliamentary Question Time. The first systematic study on this topic was undertaken by Rasiah $(2007,2010)$ who set out to investigate evasion practices in parliamentary Question Time in Australia, the case of the Iraq war. ${ }^{1}$ In addition to generating informative results, the major contribution of her research has been the formulation of the comprehensive, unified framework for the study of evasion based on the combination of theoretical frameworks and models proposed in the relevant literature. Recently, the same subject came under scrutiny, but this time evasion was examined alongside hedging in both the UK and Australian Question Time (Nevrkla, 2017) applying Partington's (2003) model.

Therefore, this study is expected to contribute in several respects. On the one hand, it can provide additional insight into evasive practices in parliamentary discourse and, on the other, extend our understanding of the political discourse in Serbia. Furthermore, it can fill obvious research gaps since, to the best of my knowledge, no previous study has addressed either evasion in Serbian political discourse or the Serbian Parliamentary Questions language.

\section{METHODOLOGY}

\section{Parliamentary Questions and the Data}

Prime Ministers Questions in the British House of Commons is said to show democracy at its best (Beard, 1999, p. 105). Accordingly, this parliamentary practice from the "mother of parliaments" (Bayley, 2004, p. 7) has spread to other countries. Since February 2009, the members of Serbian

\footnotetext{
${ }^{1}$ The studies addressing parliamentary discourse frequently focus on the topical issues
} discussed in the parliaments. 
Parliament (MPs) have been entitled to pose questions to the Prime Minister (Pr. Min.) and Government ministers (Min.). In accordance with the Rules of Procedure, Parliamentary Questions shall be posed to the Government once a month between 16:00 and 19:00 hours during an ongoing parliamentary sitting (National Assembly of the Republic of Serbia). The course of communication is heavily regulated with imposed time limits. Every MP is entitled to pose verbal questions within one question turn of up to three minutes. A competent Government member immediately replies verbally for five minutes at most, after which the enquirer is entitled to comment on the response, or ask another two follow-up questions. Upon hearing the response, the questioning MP can declare their opinion on the reply received.

The publicly available Parliamentary Questions stenographic transcripts (unregistered and unauthorised) during three sessions of the National Assembly in October 2017, March and April 2018 ${ }^{2}$ comprised the data for this study. These parliamentary questions were posed verbally and regarding the current issues of general interest. The structure of the data is outlined in Table 1.

Table 1. Data

\begin{tabular}{lccc}
\hline & \multicolumn{3}{c}{ Parliamentary Questions } \\
\hline Session & $\begin{array}{c}2^{\text {nd }} \text { session of } 2^{\text {nd }} \\
\text { regular sitting }\end{array}$ & $\begin{array}{c}2^{\text {nd }} \text { session of } 1^{\text {st }} \\
\text { regular sitting }\end{array}$ & $\begin{array}{c}4^{\text {th }} \text { session of } 1^{\text {st }} \\
\text { regular sitting }\end{array}$ \\
\hline Date & $26 / 10 / 17$ & $29 / 3 / 18$ & $26 / 4 / 18$ \\
Word count & 22539 & 24227 & 23494 \\
\hline
\end{tabular}

\section{Procedure}

The question-reply exchanges in the data did not follow the same structure and considerably diverged in terms of the number of the questions they contained, length and additional accompanying speech. Therefore, the special attention was paid to single out the core part of the question(s) within the question blocks. In case the identified question was immediately followed by explanatory sub-questions, they were not considered. Follow-up questions were also included in the analysis. ${ }^{3}$ Since each question can elicit more than one response by the Government members, all reply turns were then analysed to identify responses matching the posed questions.

The responses were classified into answers (if the answer was provided by at least one Government member), intermediate responses

\footnotetext{
${ }^{2}$ http://www.parlament.gov.rs/активности/народна-

скупштина/посланичкапитања/посланичка питања.86.html

${ }^{3}$ These were counted as new questions.
} 
and evasions based on the criteria set forth below. They were manually categorised and separately analysed. Given the focus of the study, each identified evasive response was further scrutinised. First, its level of evasion was determined. Secondly, the practices employed were investigated. The agenda shifts (shift the subject/topic) were considered a specific feature so that evasive responses were finally analysed in terms of the shifts that occurred if any.

The study employed both quantitative (questions and distribution of responses) and qualitative methods.

\section{Analytical Framework}

The framework applied in this study drew on the models previously successfully applied to investigate evasion in the political discourse, notably from Rasiah's (2010) framework with some modifications. The following operational definitions were used as a benchmark from which the utterances of relevance were assessed.

Questions are utterances which require information and opinions that the questioner does not know (Beard, 1999, p. 98). They were classified into: yes-no questions (typically starting with a two-word question particle ( $d a l i)$ or with the auxiliary or main verb followed by the particle $l i$ to which the expected answers are affirmation or negation (Bull, 2003, p. 102)) and content questions ${ }^{4}$ (that contain an interrogative word (kada (when), ko (who) etc.) and expect an answer from an open range of replies (Bull, 2003, p.p. 102-105)). ${ }^{5}$ In addition, indirect requests for information and opinions were analysed since the criteria for constituting answers can also be applied to these non-interrogative questions (Bull, 2003, p. 103). However, the questions in the form of general commentaries containing declarative utterances were excluded as they lacked any identifiable focal point so that the criteria set forth below were inapplicable.

Whatever follows the question is a response, while answers are the responses that fully satisfy the questioner (Partington, 2003, p. 234) by providing all the necessary information to the request. Within the discourse analysis of politicians talk, an answer is considered an action that addresses the agenda of topics and tasks posed (Clayman, 2001, p. 407). Thus, an answer to a yes-no question is a response which clearly confirms or negates the proposition or the one that provides "information to the questioner, which helps him/her locate the answer within a slot in

\footnotetext{
${ }^{4}$ Otherwise termed as content questions or interrogative word questions.

${ }^{5}$ Alternative (Beard, 2000) or disjunctive questions (Rasiah, 2010) were not found in our data.
} 
the yes/no continuum" (Rasiah, 2010, p. 666). ${ }^{6}$ As regards the content questions, an answer "supplies a missing variable", (Partington, 2003, p. 105; Rasiah, 2010, p. 668), i.e. the information needed to a questioner to complete the proposition truly. The following exchange provided by Rasiah (2010, p. 668) illustrates Minister Downer's implicit answer to a yes/no question:

1) MP: ... do you recall saying ...?

Downer: I appreciate the honourable member quoting what I said in my answer last week ...

Intermediate responses were regarded as an intermediary category between answers and evasions. In brief, they include refusals to answer on grounds of inability, because of national security and the responses directed towards question's presuppositions (Rasiah, 2007, 2010). Rasiah (2010, p. 669) offers the following example to illustrate one type of the intermediate response: "in response to MP's question on whether the Government had been informed of detailed plans for a 'US military administration of Iraq', the minister replied that the full details were 'yet to be settled"'. Intermediate responses also comprise other responses to the questions that could not be answered based on objective grounds as specified below. In this respect, this framework largely complies with Rasiah's (2007, 2010) approach, yet it departs from some previous proposals (Bull \& Meyer, 2003; Partington, 2003). Therefore, some types of intermediate responses in this study can be considered evasive strategies within other approaches to the phenomenon.

The responses that do not satisfy these criteria were considered evasions (evasive responses). The following is one example of the exchange containing an evasive response provided by Rasiah (2010, p. 670):

2) MP: When Prime Minister Howard meets President Bush later today in Washington, will he be telling the President that there will be no Australian military participation in any action against Iraq without a second UN resolution?

Acting Pr. Min.: The Prime Minister will be taking this opportunity to express Australia's strong preference for a new Security Council resolution ...

Since evasion is a multidimensional concept (Bull, 2008), following Rasiah's $(2007,2010)$ approach three dimensions served as the cornerstones of the analysis: level, practices and shifts. As regards the levels of evasion, each evasive response was categorised as one of the following: full evasion

${ }^{6}$ Unlike Rasiah's framework $(2007,2010)$, we did not distinguish between direct and indirect answers. 
(when a question is neither answered nor acknowledged (Rasiah, 2010), substantial evasion (which involves a significant change in the topic by the respondent (Clayman, 2001)), medium level of evasion (a response within the parameters of the topic but that performs a task entirely different from that required by the question (Clayman, 2001)), and subtle evasion (the instances involving a subtle shift that changes the terms of the question so slightly that it appears the respondent is answering the question (Rasiah, 2007)). Further, evasive responses can include covert and/or overt practices identified by Clayman (2001). Finally, based on the classification proposed by Rasiah (2010), which is mainly derived from Bull and Mayer's (1993) typology of non-replies, the respondents can resort to three types of agenda shifts, one of which contains three subtypes.

\section{RESULTS AND DISCUSSION}

\section{Questions and Responses}

During the observed Parliamentary Questions sessions, 103 questions were posed. The vast majority were clearly formulated direct ones framed after introductory "my question is" or similar clauses. Only a few questions were presented as polite requests for information containing verb zamoliti (ask) preceded by a volitional verb želeti (want), usually additionally mitigated by verbal mood. Questions were more frequently framed as content questions $(58 ; 56.31 \%)$, as shown in Table 2 which presents the results of the quantitative analysis.

Table 2. Questions and responses

\begin{tabular}{lcccccc}
\hline & \multicolumn{3}{c}{ Questions } & \multicolumn{3}{c}{ Responses } \\
\cline { 2 - 7 } & Content Qs & Yes-no Qs & Total & Answer & Intermediate r. & Evasion \\
\hline $26 / 10 / 17$ & 21 & 10 & 31 & 14 & 3 & 14 \\
$29 / 3 / 18$ & 16 & 17 & 33 & 21 & 2 & 10 \\
$26 / 4 / 18$ & 21 & 18 & 39 & 7 & 17 & 15 \\
\hline Total & 58 & 45 & 103 & 42 & 22 & 39 \\
\hline
\end{tabular}

As Table 2 shows, more than a fifth of all responses were considered intermediate $(22 ; 21.36 \%)$. A possible explanation for this might be the choice of methodology. For instance, attacking the question is a frequent form of non-reply (Bull \& Meyer, 2003) and, hence, one of the ways of evading answers (Partington, 2003). These instances were, however, not classified evasions for "it would have been unfair to expect a politician to respond to a question with a straightforward/direct answer if the presupposition(s) of the question itself was/were incorrect" (Rasiah, 2010, p. 669). Thus, intermediate responses comprise the instances of not providing answers on the grounds of an incorrect premise of the question, 
an incorrect presupposition of the question, and the wrong facts included in the question, as the following examples illustrate respectively:

3) Ja ne znam više kako da odgovaram na ovakve neistine? /I do not know anymore how to respond to such falsehood? (Prim. Min. A. B. 26/4/18),

4) Meni je kao prvo jako zanimljiva formulacija ... /First of all, it's a very interesting formulation to me... (Prim. Min. A. B. 26/10/17),

5) Što se ovih podataka o BDP tiče, ... nisam sigurna da razumem o čemu on priča... /As for these data on GDP, ... I'm not sure I understand what he's talking about... (Prim. Min. A. B. 26/10/17)

Also, this category includes the special cases of refusing to answer, although it might be claimed that they constitute another practice in not answering a question. For instance, faced with incompetence to answer due to the lack of knowledge of the issue being addressed, claims of ignorance in Partington's (2003) terms, the Ministers typically acknowledged this and promised to deliver the answer as soon as possible. These were classified as intermediate responses and so were the responses claiming that the question was outside the responsibility scope such as:

6) Policija ne vodi istragu, to radi tužilaštvo i oni mogu dati informaciju... /The Police are not conducting an investigation, the Prosecution is doing it, and they can provide the information... (Min. N. S. 26/10/17))

A relatively high proportion of the intermediate responses can also be attributed to the adversarial nature of the questions, which applies not only to the questions directed towards Government members but also to the ones explicitly hostile against Opposition. Namely, 7 questions posed in one question turn by the MP belonging to the governing coalition were not, in fact, genuine requests for information, but rather a means of attacking opposition by accusing them of corruption. The Prime Minister's response concurrently addressing them all by promising that "everything will certainly be investigated" (Prim. Min. A.B. 26/4/18), hence implying the lack of information at hand, accounted for 7 intermediate responses in the study.

\section{Evasion}

As the findings presented in Table 2 revealed, evasion did occur in the language of Serbia's Parliamentary Questions. In view of the results of previous studies (Nevrkla, 2017; Rasiah, 2007, 2010), this should come as no surprise. When compared to the data obtained by Nevrkla (2017), evasion rate was significantly lower in Serbian $(39 ; 37.86 \%)$ than in the UK and Australian Question Time (84.03\% and $66.67 \%$ respectively), whereas in comparison to Rasiah's $(2007,2010)$ findings, evasions in Parliamentary 
Questions significantly outnumbered those in Australian Parliament $(21.83 \%)^{7}$.

The reasons underlying such discrepancy in the results on the evasion rate could be at least twofold. For one thing, it can be best accounted for by the chosen methodology, as evidenced by the results obtained from the analyses carried out in the same Question Time setting (Rasiah (2010) and Nevrkla (2017) in Australia's Parliament). Nevrkla's (2017) study relied on Partington's (2003) methodology so that evasion comprised some types of responses that were categorised as intermediate ones in Rasiah's (2010), as well as in this study. Further, the discrepancy could be possibly explained by the differences between the samples analysed. Nevrkla's study analysed the textual material from three sessions unrelated to any specific topic held in February 2015, whereas Rasiah's (2010) analysed sample included transcripts of the sessions held in February and March 2003 dealing with the Iraq war, a quite sensitive topic of interest to the wider audience, i.e. the prospective voters. It is worth noting that according to the rules and regulations, there is not much difference among the questioning procedures in the three investigated question times: MPs and/or Ministers are posed oral questions without notice. Since questions are not known in advance, the possibility of pre-prepared responses is minimised. However, whether it is non-existent is highly debatable, especially given that "there is a certain amount of skepticism towards parliaments and their activities" (Bayley, 2004 , p. 9). Hence, the observed discrepancy in the results would be best explained from the standpoint of a political scientist. From a point of view of a linguist, the results are valuable as they show evidence of evasion as a notable feature of the question time discourse.

Levels. The level of evasion ranged from full to middle evasion. Full evasion was not a highly employed means by Serbian Ministers: 7 (6.8\%) questions were fully evaded, 3 of which were repeated. For instance, the MP M.Z. repeated the ignored question regarding a turning point or a change in the Government's policy on the issue of abductions and murders in Strpce, Sjeverin and the response obtained is a good illustration of substantial evasion. After expressing her sympathy and understanding for the MP's frustration, the Prime Minister went on to give examples of the "easy things the Government had done" including the compilation of an address register, accomplishments in the healthcare mentioning the data on the provided jobs and specialisations, and ended up commenting on the percentage of the irrigated land in Serbia (Pr. Min. A. B. 26/10/2017). This type of moving to an entirely different topic or area of discussion occurred in only $4(4.25 \%)$ responses.

\footnotetext{
${ }^{7}$ The percentages are given based on the calculation of the data provided in the studies.
} 
On the other hand, medium level of evasion was the most frequent among the evasive responses. The response to the question whether it was true that DES (a company for professional rehabilitation and employment of persons with hearing impairments) would be closing in May and what the employees should do is an instance of a response that performs a task entirely different from that required by the question. Namely, Minister Z . Đ. (29/3/2018) shifted from the question's task, which required him to confirm the truth of the proposition and address the potential closure of the company and the specific date, to expressing Government's eagerness to help the disabled and the companies employing them. The instances involving a subtle evasion were not observed in our data.

Practices. The analysis revealed two practices covert in nature in evading answers. Officialese/diplospeak, including generalisation and vague language, is one way of evading a question (Patrington, 2003). It is, in fact, closely related to the general observations on politicians talk that is at times opaque, unspecific, or empty (Crystal, 1997, p. 378). This could be noticed during question-answer sessions in Serbian Parliament as example 7) illustrates. Having been asked whether she was ready to sign a legally binding agreement with Priština, the Prime Minister responded:

7) ...boriću se svaki dan da nađemo najbolje moguće rešenje iz teške situacije za sve građane .../...I will fight every day to find the best possible solution from a difficult situation for all citizens ....". (Pr. Min. A. B. 26/4/18)

Another covert practice used by politicians to conceal the fact that they are shifting away from the questions (Rasiah, 2010, p. 671) is operating on the question illustrated by example 8). Faced with the question of whether and when pensions would be restored to the full amount, the Prime Minister adjusted the question to fit the intended response, i.e. justifying the measures of fiscal consolidation. Hence, explicit 'question reformulation' was used to shift the topical agenda (Clayman, 1993).

8) Zašto? To je pravo pitanje. Zašto su morale da budu obuhvaćene penzije? /Why? That's the real question. Why did the pensions have to be included? (Pr. Min. A. B. 26/10/17)

The Government members also applied open practices in evading answers. Token request for permission occurs "when the respondent appears to be asking for permission to shift the topic but does not wait for the permission to be granted before proceeding with his/her response" (Rasiah, 2010, p. 671). Example 9) illustrates this practice.

9) Ispričaću jednu anegdotu, ako mi dozvolite. /I'll tell an anecdote if you allow me. (Min. B. N. 29/3/2018)

Arguably, it also illustrates evasion by humour. Although humour is not typically used in the Parliamentary Questions, here the Minister 
resorted to it after a token request for permission. Thus, example 9) also reveals one important aspect of evasiveness: the occurrence of practices in combination.

Two evasive practices combined in one sentence can also be noticed with the response 10) in which the adverb samo downgrades what is about to be said, i.e. serves to minimise the digression from the question's agenda. Hence, in agenda shifting the Minister applied minimising the divergence whereby the respondent "downplays or gives the perception of minimising the departure from the question's agenda" (Rasiah, 2007, p. 90). To further minimise the divergence, the temporal minimiser was also used (samo kratko just briefly).

10) Shodno tome, dozvolite mi samo da navedem nekoliko podataka... /Accordingly, let me just give you some data... (Min. I. D. 26/4/2018)

Another covert practice revealed was justifying the shift. Occasionally the respondents justified or explained their shifts from the question's agenda on the grounds of subjective desire to share their views or information as in:

11) Imala sam veliku želju da dođem ovde odgovaram na pitanja ... a isto tako da kroz odgovore predstavim šta smo uradili u prvih 100 dana ... II had a great desire to come here to answer the questions ... and also to present through the responses what we have done in the first 100 days ... (Prim. Min. A. B. 26/10/17)

More commonly the shifts in responses were justified by attributing the importance on the part of the public as the following illustrates:

12) Izneću vam samo nekoliko fakata i mislim da je to jako važno da se zna i zbog celokupne javnosti. /I'll just give you a few facts and I think it's very important to know them for the entire public as well (Min. B. N. 26/10/17).

Agenda shifts. So far, it is clear that making agenda shifts, or topic management (Nevrkla, 2017), was a frequent means in Serbian Parliament. What follows is a list of topics the Ministers shifted to in their attempts to avoid answering questions.

As expected, one shift observed involved attacking the questioner. However, given the structure of the Parliamentary minority and the fact that all the attacks noted were directed at the questioners belonging to the Opposition parties, a boundary between this shift and attacking opposition seems rather blurred. Attacking opposition or other rivalry groups, external attacks (Rasiah, 2007), was a prominent shift. ${ }^{8}$ By way of illustration, in a

\footnotetext{
${ }^{8}$ Apart from the opposition, i.e. previous government, there were no instances of attacking others.
} 
previously stated response to the question about the DES company, the Minister shifted from the question's task to point to "one bad and a catastrophic situation in these companies" that they had inherited due to "irresponsible policy that had been pursued until 2011" which had led them "to the verge of existence" (Min. Z. Đ. 29/3/18). This example clearly illustrates the prominent practice of attacking the previous "incompetent government" (Min. Z. Đ. 26/10/17) and "irresponsible politics" due to which in 2012, "the country was devastated" (Prim. Min. A. B. 26/4/18) and "found in a catastrophic state" (Min. N. S. 26/10/17).

Occasionally, the complexity of the questions put to Ministers accounts for this agenda shift. In cases when questions contained multiple presuppositions and assertions, typically of adversarial nature, a straight and simple answer was rarely an option. To illustrate, in his response to the question enquiring when the Government would begin to obey the laws that it had adopted including the media law, the Minister responded:

13) Ovo što se medija tiče, to ste nas pomešali sa Đilasom. To je tako bilo onda. /As regards the media, you confused us with Đilas. That's how it was at the time. (Min. N. S 26/10/17)

Although it was a content question, the straight answer, e.g. next month, could hardly have been expected as the presuppositions carried by the question were the accusations of corruption. The negative tone was retained in the Minister's response as he resorted to a counter-attack aimed at the MP's accusations. This also confirms the confrontational nature of the discourse in which question-response sequences often display exchanges of mutually accusatory replies between opposition MPs and government MPs (Ilie, 2015).

Along with external attacks, making political points as a broader shift also comprises talking up one's side. Typically, Government members made agenda shifts to presenting Government in a positive light. The shifts frequently focused on portraying the Government as a successful, "open, democratic and responsible" (Pr.Min. A. B. 26/4/18) and on presenting everything that had been done and achieved on "the successful recovery path of Serbia that began in 2012" (MP Đ. K. 26/10/17). Comparisons with the previous Government and current Opposition were often supported by the ample statistical data. The above-stated instance of substantial evasion illustrates three shifts made within a single response to a positive portrayal of the Government.

Rasiah (2010) identified the shift to presenting policy as a third way to make political points. In our data, clear instances of its occurrence were not found as it was usually combined with the shifts and practices previously discussed.

As regards the third type of agenda shifts, stating the question had already been answered, only one instance was found: 
14) Što se tiče ubistva Olivera Ivanovića, mislim da ste dobili jasan odgovor od MUPa. /As for the murder of Oliver Ivanović, I think you received a clear answer from the MIA. (Prim. Min. A. B. 29/3/18)

In all identified evasive responses, at least one agenda shift occurred either singly or in any combination with the above-discussed practices. As regards the types of agenda shifts, the findings are in line with those on evasion in Australia's Question Time that the most prominent shifts made included 'positive self-presentation' and 'negative other-presentation' (van Dijk, 2005), frequently co-occurring (Rasiah, 2010). However, in our data, they did not appear only as a form of evasion but alongside a provided answer as well. As Rasiah (2007, p. 60) noted, the term is derived from the phrase agenda-shifting procedures introduced to denote means by which a politician may change the topic of conversation either before or after giving their reply. This accounts for the noticeable occurrence of agenda shifts in the majority of responses irrespective of the numbers of answers provided to a question. For instance, the question asking how it was possible that in the $21^{\text {st }}$ century Novi Pazar had no railway, no gas, and the worst roads in the whole country elicited 4 responses all of which involved agenda shifts to making political points. In this regard, Serbian Parliamentary Questions share features with the UK Question Time in which after answering the question the podium uses the remaining allocated time to make political statements or to attack political opponents (Nevrkla, 2017, p. 94).

Our data also confirm the claim that 'departures from the question's agenda' may not necessarily be treated as inadequate by enquirers (Clayman, 2001, p. 407) since in numerous instances MPs did not express their dissatisfaction with the evasive responses obtained. Furthermore, in some instances, the very questions seemed to be much more about attacking the opposition, as mentioned previously, and political points scoring rather than obtaining an unbiased response on a significant subject. This supports Rasiah's (2010, p. 673) observation that politicians indirectly use Question Time as a forum to further their own agendas.

\section{CONCLUSION}

The study set out to determine whether Government members evade questions in Serbian Parliamentary Questions. As regards the set aims, the study has revealed the following:

- evasion occurred recurrently at Parliamentary Questions, the evasion rate being of $37.86 \%$;

- evasive responses ranged in terms of level from full to middle level of evasion, the latter being the most prominent one;

- various practices were employed by Ministers in evading answers (generalisation and vague language, operating on the question, 
token request for permission, minimising the divergence, justifying the shift);

- agenda shifts were a typical feature of the evasive responses (attack the questioner and make political points (external attacks, talk up one's side, present policy))

- the practices and shifts identified were not mutually exclusive and tended to co-occur within a single response.

We can conclude that the results have provided further support to the stereotype of politicians as evasive, even in question time settings. The results on the evasion style in Parliamentary Questions match those observed in similar studies (Nevrkla, 2017; Rasiah, 2010). In this regard, the study has contributed to the field of parliamentary discourse research and added up to the rare studies on evasion in this political setting.

Although the study has offered some new insights, its possible limitations need to be acknowledged. Possibly the most important one lies in the quantitative analysis given the complexity of the data and the chosen methodology. In this respect, a limitation could be not using several raters to assess the level of evasion, so as to reduce possible subjectivity and enable the calculation of interrater reliability. ${ }^{9}$ The analysis based on another theoretical framework could yield different results. Nonetheless, the study has pointed to an under investigated area of research, delineated the most prominent issues involved and paved the way for future studies. Future research could focus on evasion in other genres and subgenres of Serbian political discourse and enable comparison of the results.

\section{REFERENCES}

Bavelas, J. B., Black, A., Bryson, L., \& Mullett, J. (1988). Political Equivocation: A situational explanation. Journal of Language and Social psychology, 7, 137-145.

Bayley, P. (2004). Introduction. The whys and wherefores of analysing parliamentary discourse. In P. Bayley (Ed.), Cross-Cultural Perspectives on Parliamentary Discourse (pp. 1-44). Amsterdam: John Benjamins.

Beard, A. (2000). The Language of politics. London: Routledge.

Bull, P. \& Mayer, K. (1993). How not to answer questions in political interviews. Political Psychology, 14 (4), 651-666.

Bull, P. (2003). The Microanalysis of Political Communication: Claptrap and Ambiguity. London: Psychology Press.

Bull, P. (2008). Slipperiness, evasion and ambiguity: Equivocation and facework in noncommittal political discourse. Journal of Language and Social Psychology, 27(4), 333-344.

Clayman, S. E. (1993). Reformulating the question: a device for answering/not answering in news interviews and press conferences. Text - Interdisciplinary Journal for the Study of Discourse, 13(2), 159-188. doi:10.1515/text.1.1993.13.2.159

\footnotetext{
${ }^{9} \mathrm{I}$ am greatly indebted to an anonymous reviewer who has pointed to this limitation.
} 
Clayman, S. E. (2001). Answers and evasions. Language in Society [Online] 30 (3), 403442. Retrieved 15 May, 2018 from http://journals.cambridge.org/bin/ bladerunner

Crystal. D. (1997). The Cambridge encyclopedia of the English language. $2^{\text {nd }}$ ed. Cambridge, New York: CUP.

Greatbatch, D. (1986). Aspects of topical organization in news interviews: the use of agenda-shifting procedures by interviewees. Media, Culture \& Society, 8(4), 441-455.

Hanafe, N. Z. \& Thani, S. R.M. (2016). Evasion Strategies by Politicians in News Interviews. Malaysian Journal of Languages and Linguistics, Vol 5, No 1, 10-30. Retrieved 5 May, 2018 from http://www.journals.mymla.org/index.php/MJLL/ issue/view/7

Ilie, C. (2004a). Insulting as (un)parliamentary practice in the British and Swedish Parliaments: A rhetorical approach. In P. Bayley (Ed.), Cross-cultural perspectives on parliamentary discourse (pp. 45-86). Amsterdam: John Benjamins.

Ilie, C. (2006). Parliamentary discourses. In K. Brown (Ed.), Encyclopedia of Language and Linguistics. $2^{\text {nd }}$ ed., Vol. 9 (pp. 188-197). Oxford: Elsevier.

Ilie, C. (2010). Strategic uses of parliamentary forms of address: The case of the UK Parliament and the Swedish Riksdag. Journal of Pragmatics, 42(4), 885-911. doi:10.1016/j.pragma.2009.08.017

Ilie, C., (2015). Parliamentary Discourse. In K. Tracy (Ed.), The International Encyclopedia of Language and Social Interaction (Volume 3) (pp. 1113-1127). London: Wiley Blackwell. Retrieved 15 May, 2018 from https://www. researchgate.net/publication/303459695_Parliamentary_Discourse

Ilie, Cornelia. (2004b). Interruption patterns in British parliamentary debates and in drama dialogue. In A. Betten and M. Dannerer (Eds.) Dialoganalyse IX - Dialogue in Literature and the Media (pp. 311-326). Tübingen: Max Niemeyer Verlag.

Murphy, J. (2014). (Im)politeness during Prime Minister's Questions in the UK Parliament. Pragmatics and Society, 5(1), 76-104.

National Assembly of the Republic of Serbia. Rules of Procedure of the National Assembly. Retrieved 6 June, 2018 from http://www.parlament.gov.rs/nationalassembly/important-documents/rules-of-procedure-(consolidated-text)/thenational-assembly-service.1370.html

Nevrkla, L. (2017). Evasion and hedging in the language of parliamentary Question Time. Linguistica Pragnesia, (27) 2, 83-95. Retrieved 28 March, 2018 from https://linguisticapragensia.ff.cuni.cz/wpcontent/uploads/sites/12/2017/10/LP_2017-2_Nevrkla_83-95.pdf

Partington, A. (2003). The Linguistics of Political Argument: The Spin-doctor and the Wolf-pack at the White House. London and New York: Routledge.

Rasiah, P. (2007). Evasion in Australia's Parliamentary Question Time: The case of the Iraq war (Unpublished $\mathrm{PhD}$ thesis). University of Western Australia, Perth. Retrieved 6 May, 2018 from https://research-repository.uwa.edu.au/en/ publications/evasion-in-australias-parliamentary-question-time-the-case-of-the

Rasiah, P. (2010). A framework for the systematic analysis of evasion in parliamentary discourse. Journal of Pragmatics, 42, 664-680. doi:10.1016/j.pragma.2009.07.010

Van Dijk T. A. (2005) War rhetoric of a little ally: Political implicatures and Aznar's legitimatization of the war in Iraq. Journal of Language and Politics, 4(1), 65-92

Van Dijk, T. A. (2000). On the analysis of parliamentary debates on immigration. In M. Reisigl \& R. Wodak (Eds.), The semiotics of racism. Approaches to Critical Discourse Analysis (pp. 85-104). Vienna: Passagen Verlag.

Van Dijk, T. A. (2004). Text and context of parliamentary debates. In P. Bayley (Ed.) Cross-cultural perspectives on parliamentary discourse (pp. 340-372). Amsterdam: John Benjamins. 
Vuković, M. (2013a). Adversarialness and evasion in broadcast political interviews. International Journal of Language Studies, Vol. 7, No. 4, 1-24.

Vuković, M. (2013б). Slaba epistemička modalnost u crnogorskom parlamentarnom diskursu [Weak epistemic modality in Montenegrin parliamentary discourse]. Filolog, 7, 65-76. doi:10.725 1/FIL1307065V)

Vukovic, M. (2014). Strong epistemic modality in parliamentary discourse. Open Linguistics, 1(1), (Online) 37-52. doi:10.2478/opli-2014-0003

Vuković Stamatović, M. (2016). Scaling deontic modality in parliamentary discourse. Logos \& Littera: Interdisciplinary Approaches to Text, 3(2), 131-149.

Векарић, Г. \& Јелић, Г. (2014). Језички изрази говорног чина извињења у српском парламентарном дискурсу. У Мишић Илић Б. и В. Лопичић (Ур.). Језик, књижевност, дискурс: Језичка истраживања. (315-326). Ниш: Универзитет у Нишу, Филозофски факултет.

\title{
ЕВАЗИВНОСТ У ПОСЛАНИЧКИМ ПИТАЫИМА СКУПШТИНЕ СРБИЈЕ
}

\author{
Александра Радовановић \\ Универзитет у Крагујевцу, Факултет за хотелијерство и туризам \\ у Врњачкој Бањи, Врњачка Бања, Србија
}

\section{Резиме}

Политичаре неретко сматрамо људима који „неће дати директан одговор на директно питање" (Бул, 2003, стр. 130). Стога не чуди да је евазивност у политичком дискурсу предмет бројних истраживања у области социјалне психологије која су потом инспирисала и језичка испитивања овог феномена. Анализе су, међутим, у великој мери ограничене на контекст политичких интервјуа у медијима, док је евазивност у парламентарном дискурсу недовољно истражена. Имајући то у виду, евазивност током посланичких питања, као једном од репрезентативних поджанрова парламентарног дискурса, налази се у средишту истраживања овог рада. Намера аутора је да истражи евазивност током посланичких питања у Народној скупштини Србије са циљем да испита да ли су и колико често чланови Владе избегавали одговоре на питања и како су то чинили.

Квалитативна и квантитативна анализа спроведена је на материјалу сачињеном од транскрипата посланичких питања са три седнице Народне скупштине одржане у октобру 2017, марту и априлу 2018. године. Аналитички оквир заснован је на моделима који су претходно успешно примењени за испитивање евазивности у политичком дискурсу, посебно на моделу који је предложила Разија (2010). Језички материјал је анализиран на основу постављених критеријума за одређивање питања и типова одговора. Одговори су класификовани као „прави одговори”, посредни одговори и евазивни одговори, а сваки идентификовани евазивни одговор је потом даље анализиран у погледу нивоа евазивности, примењених техника и промена тема до којих је дошло.

Резултати показују да се у испитиваном материјалу више од петина одговора може сматрати посредним (22 од 103; 21,36\%), као и да евазивност јесте присутна код значајног броја одговора на питања посланика (39 од 103; 37,86\%). Када је реч о нивоу, најучесталији су одговори средњег степена евазивности, а уочено је и потпуно одсуство давања одговора на постављено питање. Као што је у раду описано и 
поткрепљено примерима, чланови Владе су примењивали различите технике у избегавању одговора, како прикривене (уопштавање и нејасан језик, преформулисање питања) тако и отворене (захтев за дозволу за промене теме, минимизирање одступања и оправдавање промене). Промена теме представља типичну одлику евазивних одговора. Три теме су уочене у материјалу: напад на испитивача/опозицију, стицање политичких поена (спољни напади, заговарати нечију страну, садашња политика) и тврдња да је на питање већ одговорено. Уочене технике и промене тема нису међусобно искључиве. У свим идентификованим евазивним одговорима појављује се најмање једна промена тема, самостално или у било којој комбинацији са горепоменутим техникама.

Ови резултати су у сагласности са резултатима претходних студија о евазивности током посланичких питања у другим парламентима. 